\title{
Strategy Research and Training of Information Literacy of College PE Teachers
}

\author{
Xiaofang Yuan, Xianming Chen, Yong Ye \\ Wuhan Railway Vocational College of Technology, China
}

\begin{abstract}
In the era of rapid growth of information, information quality in information ability as the core will become an important means of individual cognition in the information age, become basic survival skills. College teachers should first have the information literacy comprehensive. But the information quality of teachers of college sports in China is generally low, to some extent influence the development of College Physical Education and sports teachers improve their comprehensive quality. In this paper, on the basis of literature, comprehensive use of various research methods, on the cultivation of information quality of College Physical Education Teachers in our country the necessity and status were analyzed deeply, points out the existence of information quality of College PE Teachers' problems, and puts forward strategies for cultivating the information quality of College PE teachers. In order to improve information quality and teaching level of university teachers, and promote the further development of China's PE teachers in Colleges of education reform.
\end{abstract}

KEYWORD: PE teachers; Information literacy; Development strategy

\section{INTRODUCTION}

The cultivation of information literacy is becoming a hot topic in current information education and the whole process of education informatization. With the development of information technology, information communication is developing at an unprecedented speed and width. Since the multimedia technology to process, store and transmit all kinds of information can be realized by a computer, through domestic and international data network provides people with rich educational resources, so that more and more students can gain knowledge and information through information technology. This put forward higher requirements on the quality of teachers, especially for the information literacy of teachers put forward higher requirements. In the field of physical education, teachers' information quality will directly affect the level of the college physical education quality and the success of education reform.

\section{ANALYSIS OF THE CURRENT SITUATION OF COLLEGE PE TEACHERS' INFORMATION QUALITY}

According to the definition for the international society for technology in education "all the teachers educational technology standards" and the meaning of information literacy, the author designed a questionnaire from the information knowledge, the information consciousness, the information ability and information firstly from four aspects, the present situation of information quality of college physical education teacher survey. The survey by random sampling method, the Huazhong Normal University, Huazhong Agricultural University, Wuhan Railway Vocational College of Technology and other colleges and universities took part of physical education teachers, a total of 200 questionnaires, recovery of 186 , the recovery rate is $93 \%$, effective questionnaire 180, effective questionnaire $93 \%$, recovery rate. The result of the investigation was analyzed as follows[1].

\subsection{Analysis of the current situation of College PE Teachers' information quality}

Physical education teachers in colleges and universities master degree of information and knowledge needs to be improved. The development of the information society makes information become an important resource for the social life of information. Grasp the understanding of the information knowledge and rational, combining actual teaching and scientific research of university teachers is under the adapt to the demand of the reform of higher education must have the basic qualities. The survey shows that only $33.4 \%$ of 
College Physical Education Teachers in Information Retrieval Knowledge understand completely, 69.3\% of the physical education teachers in Colleges and universities can or can the skilled operation computer, $90.7 \%$ of the teachers can or can the combination of teaching and scientific research, and teaching innovation, these are from a different point of view reflects the present college physical education the teachers of information knowledge of information technology and the degree of attention. At present college PE teachers of information cultural quality has reached a certain level, the training of information literacy of College $\mathrm{PE}$ teachers laid a certain material base.

\subsection{Analysis of the current situation of College PE Teachers' information consciousness}

As can be seen from the survey, the current physical education teachers in Colleges and universities in the information consciousness show the following characteristics: fully aware of the importance of teaching and scientific research to collect related information; can basically grasp the development trend, understand the subject knowledge and research development; most teachers can establish corresponding searching strategies in the retrieval, in order to facilitate the to improve the efficiency and speed of retrieval. 99\% of the PE teachers in Colleges and universities to actively carry out research work in the teaching work, not regularly publish research papers; $90 \%$ of the physical education teachers in Colleges and universities can or can be in peacetime gathering and professional teaching and research related knowledge and information. But in the survey we also found that physical education teachers in Colleges and universities collect information channels relatively simple, mainly through the carrier of communication paper medium, such as paper journals, books, newspapers, modernization means through the network search, email, forums and other information collection rate is low.

\subsection{Analysis of the current situation of information skills of College PE Teachers}

As can be seen from the survey, the teacher for document processing and application, the operating system of a computer multimedia principle operation skills also need to be strengthened. At present, the college PE Teachers' skills in network communication, web production, multimedia production are relatively lack. Computer system of the operation skills for the use of information technology equipment and information technology and curriculum integration plays an important role. College sports teaching for the modern network teaching situation requires physical education teachers in Colleges and universities to keep up with the pace. In the survey, we found that only $18.3 \%$ of the teachers can use multimedia in teaching practice, and the proportion of using multimedia technology to assist teaching is accounted for $45.1 \%$. The information literacy of University PE teachers is the weakest link.

\subsection{Analysis of information ethics situation of PE teachers in universities and Colleges}

In the information age, as known as "the college teachers human soul engineer", must have a certain amount of information ethics to resist on interference and influence of various harmful information. In the 180 college teachers surveyed, only $43.8 \%$ of the teachers think that information ethics should be a basic quality of college physical education teachers to access and use of information. By the above data can see, overall physical education teachers in common colleges and universities information moral consciousness, low degree of attention to information ethics.[2]

\section{ANALYSIS OF STRATEGY TRAINING FOR COLLEGE PE TEACHERS' INFORMATION QUALITY}

\subsection{Establish macro information quality education planning and assessment standards of teachers' information technology}

Countries and relevant departments should make the overall planning and comprehensive training college PE Teachers' information quality, establish and develop the independent education information organization, levels and stages of the implementation of information quality education planning. At the same time in the teachers deeply to carry out extensive publicity and education of national information policy, information law and information ethics, make every teacher can deeply understand the reality demand of information society to modern people, to develop modern information consciousness, teacher's information idea, information morality.

Draw up standards of national unity of teachers' information technology according to China's present situation of information education and college physical education teacher's information literacy. Because the information literacy standards as a measure of a kind of educational development, the research object of education and the development of education evaluation and comparison. Teacher' information technology standard is the teacher's information technology ability and quality regulations, work instructions and the information literacy of teachers. Using of information literacy standards, it can monitor the operation condition of the teachers of information technology in our country, in order to find the problem in time, to find 
out the countermeasures, thus to solve the problem.

\subsection{Strengthen the internal construction of sports information environment in Colleges and Universities}

Information literacy can be cultivated through education and learning. The improvement of teachers' information literacy is not going to do, and must be planned and periodic. Persistence and consistency. The national education system has formulated relevant training programs according to the actual situation, the actual situation of the school and all the teachers, to formulate the corresponding training goal and training strategy, training and improving university teachers information quality assurance.

\subsubsection{Sports teachers should strengthen the advanced teaching theory}

The rapid development of modern information technology promote the educational theory breakthrough development. Application of technology education based on computer and network communication technology has become a popular education theory. The development of modern information technology and education theory also promotes the reform of educational mode, at the same time of college sports teachers put forward new requirements. The essence of College PE teachers should recognize this shift. In advanced science and education theory, change the traditional teaching concept, change the traditional "Teacher centered" teaching mode, the establishment of a new "take the student as the center, information teaching emphasis on both teaching and learning". In the new teaching environment, teachers' duty to teach the knowledge of the past by directly into to the methods and skills of students to learn, teach students how to learn. In the process of learning, teachers role should be a promoting students' all-round development education, guide the students in their learning and cooperation, sports and health curriculum developers and designers, this concept should be firmly placed in every PE Teachers' teaching philosophy.

\subsubsection{Improve the network teaching environment}

To cultivate and improve the information quality of teachers, not only the need to increase the level of educational theory and the reform of teaching concept, but also cultivate their practical skills.

Therefore, all types of schools at all levels should establish a fairly complete teaching facilities, ensure that every teacher can be exposed to all kinds of modern information technology and information resources, improve the teacher's information technology ability in practical operation and use of the process. The information infrastructure construction is to develop and improve the necessary conditions of teacher' information literacy and basic work, all kinds of schools especially in Colleges and universities must have the minimum information technology infrastructure, and increasing the information technology infrastructure. The special features and sports teaching itself makes sports teachers are generally in the outdoors, there are difficulties in the use of information means of education, physical education teachers in the equipment configuration also has certain limitation, this should cause the various departments and the importance of physical education teacher's attention. To strengthen the information construction of school physical education department, such as the CAI courseware manufacture room, multimedia classroom, sports teaching CD-ROM, tape, electronic and audio-visual equipment, information network, providing the material platform for College Physical Education teachers. Sports among teachers, between the subject teachers through horizontal cooperation, cooperation with other disciplines of experts and scholars, improve their information skills.

\subsubsection{Establishe the assessment and incentive mechanism}

Information literacy is seen as the future teachers must have the quality, all teachers must have a sense of urgency and sense of career. Provide a framework for assessment and evaluation is one of the important role of standard setting is for information quality and ability, only through continuous assessment and evaluation of not only the standard form, to improve teachers' information quality objective. The school is necessary to formulate a series of incentive and evaluation system, and the establishment of two mechanisms: the incentive mechanism and the evaluation mechanism of achievement. The information technology will be applied to teaching and achieved certain teaching effectiveness of teachers in certain material rewards through training and study, make they get everybody approval, and make the mechanism of encouragement and guidance, forming a virtuous cycle. At the same time, combine the information technology standards for teachers and teacher qualification certificate system, the teacher's information technology ability as the necessary condition to obtain the certificate of qualification of teacher, teachers have the pursuit of personal and professional development, improve their information ability and information quality, the standard implementation is guaranteed in the system.

\subsection{Continuously improve the physical education teachers in Colleges and universities use the information level}

\subsubsection{Strengthen the awareness of sports teacher education informationization}

The development trend of information revolution 
and the information society demands physical education must realize information to adapt to the development of the education information, information consciousness of physical education information process depending on how the physical teachers and the level of information technology, physical education teachers in Colleges and universities as the highest level of physical education, should improve their ideological understanding. Therefore, all departments should be based on the development of education information in our country, based on the features of the discipline of physical education, extensive and in-depth publicity and education of physical education information policies and regulations, ethics, let every college physical education teachers have to deeply understand the specific requirements of modern physical education and sports teachers in information age, this the cultivation of their modern physical education consciousness, knowledge, ability and morality, make it meet the new demand of information-based physical education teachers.

\subsubsection{Strengthen the sports teacher's information knowledge and information technology training}

The information age calls for highly information quality of College PE teachers, sports teachers in Universities of our country, the use of information knowledge and information skills are still very difficult. Information technology training and the best way to solve this problem is to seize the sports in-service teachers in Colleges and universities. In the process of training, to set up the information and skills according to the difference between the actual needs and teachers of training contents and curriculum, "according to the needs of teaching, learning, pay attention to actual effect" principle. The course content specific, should include information source, printing of information retrieval and use of computer network, information retrieval, information retrieval, information processing technology, research and advisory information, computer and intellectual property protection, basic information resources sharing, computer application technology, modern education technology. In addition to offering special training courses, but also for sports teachers of colleges and universities, to hold some lectures, academic report and carry out academic exchanges and so on, it can be an effective means of information and knowledge and technical training for physical education teachers in Colleges and universities.[3]

\subsubsection{Encourage the PE teachers in teaching and scientific research and the application of information technology}

Based on the theoretical training, information technology, physical education teachers should provide opportunities and conditions for the practice of attention. The school may formulate relevant policies, encourage the teachers applying information technology in teaching and research in practice. In sports teaching, can take the information technology as teaching tools and methods to the whole process of physical education teaching, so as to cultivate the ability to use information technology to physical education teachers; teaching organization of competitions, application of information technology may be combined with the actual, borrow stimulus help competition, physical education teachers to promote the wide application of information technology in teaching practice. In the sports scientific research, sports teachers in Colleges and universities must use information retrieval technology, access to relevant information in the field of timely and effectively, this is their scientific research, establish the research direction, to promote the research process of accelerator.

\section{THE CONCLUSION}

Because of the information quality is closely related with the degree of information is proposed, a country's information industry and social fields so, for the study of information literacy and information literacy education, foreign countries started earlier, the research results are more abundant. Our country is brought out in recent years to the study of information literacy, and Research on multi reference and introduction of foreign achievements, research on physical education teachers, physical education teachers in Colleges and universities is the lack of information literacy. Therefore, based on the grasp of the basic of information quality and the information quality of the results, based on the analysis of current status of information literacy of college physical education teachers to start, discusses the necessity of cultivating information quality of PE teachers in Colleges and universities, combining with the strategies of cultivating information quality of teachers, put forward some suggestions of cultivating information quality of Physical Education Teachers University of views.

\section{REFERENCES}

[1] Xing Chunyan. The Enlightenment of. 2006 American literacy education of information literacy education in China (4).

[2] Zhang Chunfang. The information and the development of physical education. Journal of Wuhan Sports Institute,.2006 (6).

[3] Yukui, Chen Hong. The information literacy of teachers and train. Journal of Jilin Institute of Physical Education, 2005 (1). 